\begin{tabular}{|c|c|c|c|c|c|}
\hline ISRA (India) & $=3.117$ & SIS (USA) & $=0.912$ & ICV (Poland) & $=6.630$ \\
\hline ISI (Dubai, UAE & $=\mathbf{0 . 8 2 9}$ & РИНЦ (Russia) & $=0.156$ & PIF (India) & $=1.940$ \\
\hline GIF (Australia) & $=0.564$ & ESJI (KZ) & $=8.716$ & IBI (India) & $=4.260$ \\
\hline JIF & $=1.500$ & SJIF (Morocco) & $=5.667$ & OAJI (USA) & $=0.350$ \\
\hline
\end{tabular}

\section{SOI: $\underline{1.1 / \mathrm{TAS}}$ DOI: $\underline{10.15863 / \mathrm{TAS}}$ International Scientific Journal Theoretical \& Applied Science}

\author{
p-ISSN: 2308-4944 (print) e-ISSN: 2409-0085 (online) \\ Year: $2019 \quad$ Issue: $04 \quad$ Volume: 72
}

Published: $30.04 .2019 \quad$ http://T-Science.org
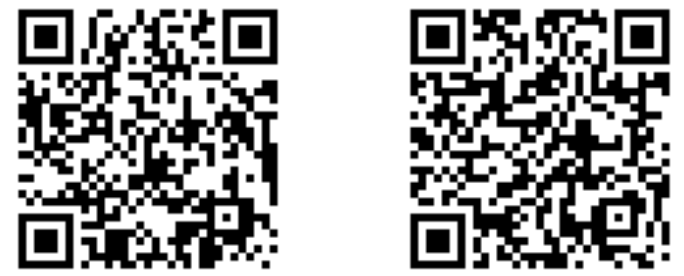

Shirina Irgashevna Zakirova teacher

Tashkent State Technical University named after Islam Karimov

Dilfuza Yuldoshevna Isroilova teacher

Tashkent State Technical University named after Islam Karimov

\title{
THE ROLE OF THE CONCEPTS OF GLOBALIZATION IN THE ENGLISH LANGUAGE
}

\author{
Abstract: The article discusses today's major sociolinguistic theories that have emerged due to the English \\ language globalization, as well as language and culture contacts. \\ Key words: language, culture, foreign language, norm, globalization, language community. \\ Language: English \\ Citation: Zakirova, S. I., \& Isroilova, D. Y. (2019). The role of the concepts of globalization in the English \\ language. ISJ Theoretical \& Applied Science, 04 (72), 459-462. \\ Soi: http://s-o-i.org/1.1/TAS-04-72-57 Doi: crossef https://dx.doi.org/10.15863/TAS.2019.04.72.57
}

\section{Introduction.}

English, one of the most powerful languages of our time, having become involved in the process of globalization, is undergoing rapid dynamic processes, observed most vividly since the last third of the 20th century. This dynamic is due to the expansion of contacting English with other languages and cultures (however, this process began from the end of the 15th century) and the development of its functions in serving the society, which was caused by political, economic, cultural and informational reasons, first of all [1].

There is no doubt that the complexity and speed of these dynamic processes, correlated with the status, change and functioning of modern English, could not but cause controversial discussion points of view, the scientific reception of which gave rise to a number of concepts, the main of which are the following: the concept of English variability, known abroad as the World English paradigm, and its related concept of English as an international language (English as an International Language, EIL); the concept of an intermediary language, or lingua franca (English as a Lingua Franca, ELF); concept of international English (International English, IE); The concept of simplified English, such as Globish, is essentially a commercialized business idea. All of these concepts, relevant to understanding the essence of modern
English, lead to reflections on its future, represented by futuristic theories, and on the social significance of these processes, illuminated by ideological theories.

The concept of English variability. One of the first theories brought about by the global spread of English was the theory of world English (world English), which was founded by American linguists Braj and Yamuna Kachru from the University of Urbana-Champaign, Illinois, and Larry Smith from the East-West Center, Created at the initiative of the University of Hawaii. The starting point in the development of this theory can be considered 1961 .

Differentiation of the English language is expressed in the existence of variants of three types (the theory of three concentric circles) [2]:

a) national variants of the English language of the Inner Circle - they are the mother tongues of people and function in all possible language functions (for example, British, American, Canadian, Australian, New Zealand English);

b) regional and local variants in the states freed from the colonial yoke, where English is the second official language and performs administrative, instrumental, interpersonal and creative functions (for example, Indian, Singaporean, South African, Nigerian and other variants of the Outer Circle);

c) regional and local variants of the Expanding Circle, performing limited functions, mainly used for 


\begin{tabular}{|c|c|c|c|c|c|c|}
\hline \multirow{4}{*}{ Impact Factor: } & ISRA (India) & $=3.117$ & SIS (USA) & $=0.912$ & ICV (Poland) & $=6.630$ \\
\hline & ISI (Dubai, UAE & $=0.829$ & РИНЦ (Russia) & $=0.156$ & PIF (India) & $=1.940$ \\
\hline & GIF (Australia) & $=0.564$ & ESJI (KZ) & $=8.716$ & IBI (India) & $=4.260$ \\
\hline & JIF & $=1.500$ & SJIF (Morocco & $=5.667$ & OAJI (USA) & $=0.350$ \\
\hline
\end{tabular}

intercultural communication and mastered through the educational system (for example, European variants, Russian, Chinese, Japanese English).

Differences of variants are based on differences of cultures on which they are based, mentality, as well as transfer characteristics of native languages for users. Differential signs of variants are observed at all levels of language and speech - in accent, vocabulary (especially in the transmission of cultural realities), syntax, and morphology, both word-wise and wordformation, in pragmatics of discourse.

The most dynamic processes occur in variants of the Outer Circle, where they form their own endonorms (first, oral, and then writing), departing from the prototypical British or American exonorm

1 - for example, in many cases, there is an endowment of nouns with a sign of discreteness and the formation of plural forms from uncountable, from the position of the British / American norm, nouns (equipments, furnitures, advices). In fairness, it should also be noted that in the Outer Circle, exonorms are often continued to be used.

All options are equal in terms of linguocultural terms - there are no options for the worst or best. It is impossible to reduce a variant (which often occurs with variants of the Expanding and Outer Circles) to the idea of an incomplete, pidginized language in which errors are identified as features of the variant. The variant of the Outer and Expanding Circles is a much more complex formation, which is a continuum, characteristic of the speech of bilinguals and consisting of at least three parts: acrolection, typical of well-educated users mainly in a formal context; the electoral characteristic of the speech of educated people in an informal context or loss of control over their speech, and the characteristic of the speech of poorly educated users.

Language variants are objects of sociolinguistics. They are an averaged phenomenon, characteristic, in general, of a certain society, but in real speech of an individual not all of his features may appear.

As can be seen from our review, the concept of options is based on linguistic, cultural and functional parameters, considering both the common features inherent in all options and their differences. However, many European linguists criticize this concept for its focus on the description of options, calling this approach to the English language "feature linguistics", but in reality, as we see, this concept is quite multifaceted, not purely descriptive [3].

Another weak point of contact variant studies is the lack of elaboration of the issue of borders and types of options: national, regional and local.

The concept of the intermediate language. At the turn of XX-XXI centuries in European linguistics has become a popular concept of English as a lingua Franca, a spin-off from the theory of options. The main difference of this concept, in strengthening of which the Journal of English as a Lingua Franca (ELF) plays a significant role, is in switching the focus of attention: the new concept focuses not on the variants, but on the description of the transnational intermediary function of the English language, its "naturally adaptive language development" [4].

From this it follows that in the theory of options more attention is paid to the relationship of language and culture, while in the concept of English as a lingua Franca, emphasizing the dynamics and instability of communication situations, variability and flexibility of the language means used, the object of the study are mainly the strategies and tactics of communication using the English language represented by different options (for example, code mixing, borrowing, regularization, the use of language redundancy, designation of understanding / misunderstanding, strengthening the value, search for clarification and explanation, paraphrasing, attention to nonverbal elements of communication, etc.

\section{International language concepts.}

English has become the language of international communication, and one of the first to develop this thesis was Larry Smith: "My working definition of an international language is the language used by people of different Nations to communicate with each other. English - the most used international language" ("My operational definition of an international language is one which is used by people of different nations to communicate with one another. English is the most frequently used international language" [5].

However, the sociolinguistic reality, as B. Kachru repeatedly pointed out, proves that the pluricentricity of the English language, i.e. the number of variants whose standard is marked as a linguistic norm, increases, which is primarily due to the awareness of the linguistic and cultural identity of the peoples using the language. The Americans were the first who realized this in the late XVIII - early XIX century.

In modern English there is no uniform standard, because in each case the Inner circle of their indoorwe are, in embodiments, the Outer circle is the emergence of private standards and the Expanding range of have a wide range of econorm, not necessarily on the British model. Thus, speaking about the international character of the English language, we must be careful, because it involves two polar opposite concepts.

The concept of simplified language. The idea of creating an artificial language for international communication has long occupied the minds of those who thought about facilitating communication between Nations. One of the first such projects involving the English language was basic English, invented in 1925 by the British linguist Charles Ogden and tested in China by Ivar Armstrong Richards. BASIC - English is often associated with the adjective 


\begin{tabular}{|c|c|c|c|c|c|c|}
\hline \multirow{4}{*}{ Impact Factor: } & ISRA (India) & $=3.117$ & SIS (USA) & $=0.912$ & ICV (Poland) & $=6.630$ \\
\hline & ISI (Dubai, UAE & $=0.829$ & РИНЦ (Russia) & $=0.156$ & PIF (India) & $=1.940$ \\
\hline & GIF (Australia) & $=0.564$ & ESJI (KZ) & $=8.716$ & IBI (India) & $=4.260$ \\
\hline & JIF & $=1.500$ & SJIF (Morocco) & $=5.667$ & OAJI (USA) & $=0.350$ \\
\hline
\end{tabular}

basic "basic, basic", which corresponds to the concept of this planned language: use only basic vocabulary (850 words +200 international words +1000 words from special fields of activity, if necessary) and basic grammatical categories. In fact, BASIC is an abbreviation of British American Scientific International Commercial "British-American scientific international commercial", and the name itself contains the purpose of this project, its commercial nature. Despite criticism, associated primarily with artificial restrictions, the idea of a basic English (not the language) have been implemented in the creation of radio programm for students (for example, Voice of America's Special English), in the preparation of technical manuals and dictionaries.

At the end of the XX century was invented and in 2004 began to implement another project - Globish (Globish, contamination global + English), the idea of which belonged to the former Vice President of global marketing for IBM's Jean-Paul Nerriere (JeanPaulNerrière). This language uses standard but simplified English grammar and limited to 1,500 words of vocabulary. The selected words, as stated by its creators, constitute a common base of vocabulary used by non-native English speakers. This vocabulary consists of neutral vocabulary, metaphorical and phraseological material is absent in it. The commercial essence of the idea is already manifested in the fact that globish is registered as a trademark and is used in courses that prepare businessmen for whom time is money to communicate in English. Globish has many offices in different countries, including Russia. In 2011 Australia established a "Fund, globish", which is a non-profit organization engaged in the publication of standards, online testing and dissemination globish.

Another school project was proposed by German linguist Joachim Grzega (JoachimGrzega) - "Basic global English (Basic Global English, BGE)" [6]. The amount included in his vocabulary - 750 basic words + Styl-lismi +250 individually selected words. Grammar consists of 20 elementary rules. Much attention is paid to the study of communication strategies. The main difference between BGE and globish and other concepts of simplification of the English language is that BGE focuses not on standard English, but on the "core lingua Franca", described by John. Jenkins [7], and admits variability. However, unlike the ELF concept, BGE does not pretend to theorize, but is an attempt to apply the idea of language simplification (which is actually a violence against language) to the practice of language teaching, which causes the commercialization of the concept itself.

\section{Futuristic concepts.}

Differentiation of the English language makes us think about its future. One of the most striking concepts of this direction predicts the death of the English language, which, as once Latin, will break up into independent languages, significantly divergent from each other. The beginning of this process is the formation of options. It is interesting that in a number of countries attempts have already been made to call the variants languages, which usually accompanies the process of a sharp rise of national consciousness, including linguocultural. So, in 1919. in the United States published a book by Henry Louis Mencken (HenryLouisMencken) "American language"; in 1945 in Australia was published the work of Sidney J.Baker "Australian language". In 1996, Canada issued a document for the assessment and training of immigrants, which is called "Milestones of the canadian language" ("Canadian Language Benchmarks"), and, despite the official bilingualism of the state, it was about English (mention of French appeared only in 2002).

According to the dynamic theory development of options Edgar Schneider [8], the options are quite long evolutionary way of development consisting of five phases: Foundation, economical stabilization of nativization, indoor stabilization and differentiation. At the last stage, which characterizes the developed national variants, there is a stylistic, dialect, sociolect stratification of the variant, bringing it closer to the status of the language.

\section{Ideological concept.}

Consideration of the processes associated with globalization, in which the English language is directly involved, would be incomplete if we omitted the theory due to ideological attitudes and attitude to this sociolinguistic reality. In fact, as R.Phillipson correctly notes [9], there is a confrontation between two paradigms in this issue - the ecology of languages and the spread of the English language.

The first paradigm is represented by the theory of linguistic imperialism, according to which the English language is accused of "linguistics" of other languages, imposing the values of Western Anglophone culture on other peoples. The result of this approach, English is endowed with a hard-hitting metaphorical definitions: it is called many-headed "Hydra" (hydra), "bully" (the bully), "the terrible and inexorable force" (Juggernaught), "Nemesis", "Siren song" (Sirensong), "invader" (intruder), etc.

\section{Conclusion.}

Modern reality poses new challenges for researchers and users of the language. Globalization of language is necessarily accompanied by its localization, complicated relations between language and society, language and culture, and this gives rise to new linguistic theories and paradigms. Their distinction is not only in conceptual and metalinguistic aspects. It is also important for sociolinguistic, evolutionary and ideological approaches that have both fundamental theoretical and applied significance. Each of the concepts analyzed in 


\begin{tabular}{|c|c|c|c|c|c|c|}
\hline \multirow{4}{*}{ Impact Factor: } & ISRA (India) & $=3.117$ & SIS (USA) & $=0.912$ & ICV (Poland) & $=6.630$ \\
\hline & ISI (Dubai, UAE & $=0.829$ & РИНЦ (Russia & $=0.156$ & PIF (India) & $=1.940$ \\
\hline & GIF (Australia) & $=0.564$ & ESJI (KZ) & $=8.716$ & IBI (India) & $=4.260$ \\
\hline & JIF & $=1.500$ & SJIF (Morocco & $=5.667$ & OAJI (USA) & $=0.350$ \\
\hline
\end{tabular}

this article has its own ideological principles, the implementation of which determines the language policy.

\section{References:}

1. Farhodjonovna, F. N. (2017). Spiritual education of young in the context of globalization. Mir nauki i obrazovaniya, № 1 (9).

2. Kachru, B. B. (1983). Models for non-native Englishes. Readings in English as an international language. (pp.69-86). Oxford.

3. Bolton, K. (2005). Where we stands: debate in World Englishes. World Englishes, Vol. 24, N 1, pp.69-83.

4. Seidlhofer, B. (2011). Understanding English as a lingua franca. (p.244). Oxford: Oxford univ. press.

5. Smith, L. E. (2008). Familiar issues from a World Englishes perspective. Kul'turnoyazekovye kontakty, Vladivostok, Vyp. 10, pp. 67-73.

6. Grzega, J. (2006). Globish and Basic Global English (BGE): Two alternatives for a rapid acquisition of communicative competence in a globalized world? J. for Eurolin-guistix, N3, pp. 1-13.

7. Jenkins, J. (2015). Global Englishes: A resource book for students. 3 ed. (p.280). L.; N.Y.: Routledge.

8. Schneider E. W. (2003). The dynamics of new Englishes: From identity construction to dialect birth. Language, Vol. 79, $N$ 2, pp. 233-281.

9. Phillipson, R. (2001). English for globalization or for the world's people? Intern. rev. of education, Vol. 47, $N_{3 / 4}^{3}$, pp. 185- 200.

10. Farkhodzhonova, N. F. (2016). Problemy primeneniya innovatsionnykh tekhnologiy $v$ obrazovatel"nom protsesse na mezhdunarodnom urovne. Innovatsionnye tendentsii, sotsial'noekonomicheskie i pravovye problemy vzaimodeystviya v mezhdunarodnom prostranstve. pp. 58-61. 